Article

\title{
LABOUR MARKET POLICIES IN DENMARK AND CANADA: COULD FLEXICURITY BE AN ANSWER FOR CANADIAN WORKERS?
}

\author{
LESLIE J NICHOLS \\ Department of Political Science, Ryerson University. \\ Toronto, Canada. ${ }^{1}$
}

\begin{abstract}
The labour market in Canada is changing. Over the past decades there has been an increase in the number of precarious workers on short-term, part-time, contracts; jobs are created and lost, as employers deem necessary. As a result of these shifts in the organization of work, many workers are now forced to hold multiple jobs in order to make ends meet. This move away from long-term employment has created a situation where the majority of Canadian workers can no longer expect their employer to provide predictable support and security for them. At the same time, under the current Employment Insurance (EI) laws, they cannot expect support from the federal government either. How can workers gain some immediate protection through expanded social welfare programmes? With more and more workers, especially women, racialized workers and lower income people relegated to precarious employment, we must question current social policy. If, as it appears, El does not work, we must strive to implement a viable alternative. Could an alternative system be modeled on the flexicurity system now in effect in Denmark? This paper draws on Nancy Fraser's criteria for social justice for the globalized worker, to assess the ways that flexicurity could improve the security of the Canadian worker by offering alternatives to participation in the market nexus.
\end{abstract}

\section{Acknowledgements}

\footnotetext{
${ }^{1}$ Leslie J. Nichols a PhD student in the Policy Studies Department at Ryerson University. She holds a Master of Arts in Work and Society from McMaster University and a Bachelor of Arts (Honours) with distinction in Women and Gender Studies and Historical Studies from the University of Toronto.
} 
I would like to thank the Labour Studies Department at McMaster University for their support of this project, especially the insights and suggestions of Dr. Wayne Lewchuk and Dr. Donna Baines and the anonymous reviewers.

\section{Keywords}

flexicurity, Nancy Fraser, employment Insurance, labour market policies, Canada

In recent years, significant changes in economic conditions throughout North America and the European Union have precipitated calls for more effective labour market policies (Pillinger 2005; Ibsen and Mailand 2010). These changes are largely due to the processes of globalization and the rapid integration of the international economy, which have resulted in intensified economic competition between nations, larger and more diverse labour markets, and the growing feminization and racialization of those markets (Pillinger 2005, 6; Näswall and De Witte 2003). The global economic crisis, which began in earnest in 2008, has only exacerbated processes of competition, the push toward reducing costs for states and for capital, at the expense of labour, and the better or at least less costly management of production. As companies are under pressure to increase efficiencies, labour markets become steadily more casualized, fragmented, flexible, mobile and internationalized. Nations scramble to encourage economic development and competitiveness, weakening social welfare systems and intensifying support to private interests. Pressures on the workforce have also intensified as a result of these changes; these pressures, including rapid and flexible skills development and fewer job security provisions, have led, in turn, to growing worker demand for a variety of job protections (Jørgensen 2009; Vermeylen 2008; Origo and Pagani 2009).

National forms of labour market policy that respond to the issues raised by these conditions vary, from more traditional approaches seen in many countries, including Canada, to more innovative 'hybrid' approaches. One such hybrid approach, currently in place in Denmark and the Netherlands, is known as 'flexicurity' (Jørgensen 2009; Vermeylen 2008). While Anglo-Saxon countries tend to take a more passive approach to labour market issues, relying mostly on relaxing labour market legislation, the flexicurity system takes a more active approach, which involves both relaxing labour market policies and supplying state worker protections and retraining programs (Solow 2008). This policy is firmly situated within neo-liberal, free-market ideology, as it focuses on adaptation by individual workers rather than systemic or structural sources of labour insecurity, although the most worker-friendly variants of flexicurity do provide workers with an important alternative to participation in the market.

Flexicurity has been referred to as the "new magic word" in Europe (Cuypers and Verhulp 2008). It was initially introduced as a way to address the increasingly flexible 
and casualized workforce that resulted from companies streamlining and downsizing their operations; temporary employment contracts created higher profits and fewer losses and helped to sustain competitiveness in the global economy. These changes, however, had a severe impact on workers' rights and living conditions (Näswall and De Witte 2003; Pillinger 2005). Negative health effects related to stress and illness increased, as did rates of absenteeism and a rising sense among workers of a general lack of control over their work and personal life (Lewchuk 2010). It became clear that, while capital is increasingly requiring workers flexibility' throughout their work lives, workers need some degree of predictability over "when and where they work" (Pillinger 2005, 50). From the strict point of view of productivity, without some job security, workers are anxiety-ridden about potential job loss and are, therefore, less productive (Näswall and De Witte 2003). So, while stable forms of employment have been shown to increase job satisfaction and worker retention rates, which in turn translate into higher productivity and profits, the economic pressures of globalization tend to militate against this option (Origo and Pagani 2009).

In practice, European Union (EU) policy makers have actively promoted the relaxation of labour standards, through the Single Market Program and via fiscal pressures created by Monetary Union (Origo and Pagani 2009; Wilthagen 2008). As a policy approach intended to enable employment flexibility while dealing with the negative effects of flexible labour on citizens' working lives, flexicurity has been a central part of these efforts (Pillinger 2005). While admittedly not an unprejudiced source and certainly not representing workers' interests, the Organization for Economic Cooperation and Development (OECD), pointing to the success of the Dutch and Danish flexicurity systems, has suggested that active labour market policies with generous unemployment benefits are the best way to protect workers (Lewchuk 2010).

In this paper I assess the feasibility of implementing the flexicurity system in Canada and examine its strengths and weaknesses against current Canadian labour market policy, specifically the Employment Insurance (EI) program. Of course, flexicurity is not a 'one size fits all' solution to labour market issues (Jacobson and Noaksson 2010, 120 ); it must take different forms in different countries depending on the specific nature of national consultation practices, among many other things (Wilthagen 2008, 256). Here I will be focusing on Denmark's version of flexicurity (Ibsen and Mailand 2010) rather than the Netherlands' approach, as Demark more closely resembles Canada's socioeconomic structure. At the same time, flexicurity is just one possible short and medium term answer to improving workers' security and employment, within what is still a broadly neoliberal framework.

In comparing Denmark to Canada, it is important to signal significant differences across the two countries. As Esping-Anderson argues, Denmark is a social democratic 
nation, while Canada is a liberal one $(1990) .{ }^{2}$ Overall, Denmark is a much more socially progressive nation than Canada; it has a culture of providing more social supports for its citizens via higher taxation and has traditionally been able to avoid high rates of low-wage work, which are quite common in liberal states (Viebrock \& Clasen, 2009). Moreover, Denmark is much more ethnically homogenous than Canada, which may have important implications for the social democratic model. In spite of these differences, the comparison of the two's countries' varying kinds and amounts of social expenditures for addressing address labour market problems remains instructive (O’Connor 1993, 502).

\section{What is Flexicurity?}

According to Elke Viebrock and Jochen Clasen, there is no universally accepted definition of flexicurity; some argue that it is a policy designed to create balance between security and flexibility in a labour market, while others believe it is about securing flexible employment (2009). The European Union (EU) Commission defines it as a strategy to enhance flexibility and security in the labour market for, both, employers and workers (Viebrock and Clasen 2009; Jørgensen 2009). As Jørgensen outlines, the EU Commission argues that there are four main dimensions of flexicurity: (1) it entrenches flexible labour market arrangements, (2) it encourages continuous lifelong learning, (3) it embodies active labour market policy and (4) it encourages stable social security systems in order to address a constantly changing labour market (Jørgensen 2009).

In relation to this, labour market analysts identify four different kinds of security that can be provided within a labour market in general: (1) job security, (2) employment security, meaning guaranteed paid employment, (3) income security and (4) combination security (Viebrock and Clasen 2009). Flexicurity strives to provide combination security; if individuals lose their jobs, they are protected by social security systems, can receive some income and are able to access retraining programs (Viebrock and Clasen 2009). So, flexicurity involves a combination of weak national employment legislation, generous replacement income and benefits when unemployed, and worker reactivation or retraining programs (Lewchuk 2010; Lewchuk et al 2011). Flexicurity does not work to recreate the "standard employment model" of forty hours a week with one employer for life - a model upon which most current social security systems are based - rather, it strives to create employable workers and helps them to move between companies

\footnotetext{
2 Canada's 2012 population of 34,670,352 is significantly larger than Denmark's at 5,475,791 (Statistics Canada Dataset 051-0005), but Denmark tends to have a somewhat higher Gross Domestic Product than Canada (OECD Statistics Gross Domestic Product). Both countries, however, have similar rates of unemployment, with 7.5 percent in Canada and 7.6 percent in Denmark according to the OECD (OECD Labour Force Statistics MEI).
} 
(Lewchuk 2010). In this way, flexibility and security are made compatible (Wilthagen 2008; Pedersen et al 2007; Lewchuk et al 2011).

Flexicurity can be seen as a model to reduce uncertainty in the employment relationship and in workers' efforts to deal with this uncertainty (Lewchuk et al 2011). Overall, it demands little overt intervention from the state or government (Solow 2008, 10) and opposes "work-first" strategies, which insist that the unemployed must take work no matter how badly paid or precarious (Lewchuk 2010), in favour of job retraining and social security. At the same time, flexicurity stresses the need to provide hiring flexibility for all employers (Madsen 2006).

Several structural elements need to be in place in order for flexicurity to be implemented; these include: (1) co-ordinated decentralization and (2) flexible multi-level governance, (3) an extended scope for bargaining and (4) "negotiated flexibility" amongst employers and workers (Viebrock and Clasen 2009, 319). During the initial implementation stages of the program, the role of the state in the creation of flexicurity is important as it introduces the required controls and enforcement mechanisms, but, over time, the state's role becomes smaller and smaller (Viebrock and Clasen 2009). In this way, flexicurity echoes neoliberal policies emphasizing a 'smaller' role for government. Vermeylen notes that, "flexicurity has the potential to substantially enhance the competitiveness of the European economy and create higher levels of employment" $(2008,209)$, but how effective has it been in practice?

\section{The Danish Case: Flexicurity}

Like the majority of Western developed countries, Denmark is a "capitalist country with a universal welfare state" (Jørgensen 2009, 15), but it is also distinct from other Western countries in several ways. For example, the service sector in both public and private parts of the economy has been the dominant form of industry for over 30 years (Jørgensen 2009). In addition, Danes have historically addressed labour market regulations in innovative ways (Viebrock and Clasen 2009, 320). Notably, in 1899, the September Compromise created a centralized negotiating body comprised of unions, government, and industry representatives to address and deal with labour market disputes (Larsen 2005). Corporatist solutions among major social partners, rather than state legislation, have remained the defining feature of Danish labour policy ever since. Major social partners in Denmark, such as trade unions and the Danish Employers' Federation (DA) (Westergaard-Nielsen 2008), along with employers and employees, bargain over wages and working hours and set protection regulations for workers, including overtime pay and issues concerning overall work environment (Westergaard Nielsen 2008). The Danish state has little direct role in such negotiations (Larsen 2005, 8) or in labour market policy more generally. It was these social partners, rather than the 
state, who developed 'flexicurity' in the 1990s as they sought to cope with the limitations of an existing work sharing system, which involved generous sabbatical leaves and other rotational schemes (Lewchuk 2010, 50) to resolve persistent unemployment (Madsen 2008, 353; Larsen 2005, 15). The Danish labour market has been very successful ever since (Larsen 2005).

The Danish flexicurity system combines liberal social provisions with minimal legislative restrictions on employers (Cuypers and Verhulp 2008; Madsen 2008); it does not provide high levels of job security but does offer high levels of Unemployment Insurance and access to courses for upgrading skills; these three elements are often termed the "golden triangle" (for instance, Larsen 2005; Vermeylen 2008; Lewchuk et al 2011). Workers are also guaranteed a global package of social rights (Vermeylen 2008). While a private institution runs the provision of unemployment insurance in Denmark, it is mostly state funded (Madsen 2008).

Of course, it is difficult to sort out the specific effects of the flexicurity programme from other structure causes of unemployment. Nonetheless, the Danish form of flexicurity has not been incompatible with reductions in unemployment and in avoiding a large low paid and precarious workforce (Lewchuk 2010, 48). In fact, unemployment fell from 12 percent in 1993 to 5 percent in 2001 (Lewchuk 2010; Jørgensen 2009), the period in which flexicurity has been in place. The length of job tenure has not been affected, as the average tenure for educated Danes, for instance, remains at eight years (Madsen 2006; Lewchuk et al 2011). Most notably, there has been a move from specific job security to overall employment security for lower skilled workers in Denmark (for insance, Origo and Pagani 2009; Lewchuk 2010; Muffels 2008). The central goal of flexicurity, then, was to make Danes more employable (Lewchuk 2010) and overall, it may have been successful in doing so; in fact, it is known as the "Danish Job Miracle", managing to avoid getting in the way of economic policy goals while maintaining the view that "no Dane should suffer economic hardships" (Andersen and Svarer 2007, 390; Jørgensen 2009, 7, 8, 12; Larsen 2005. 5; Solow 2008, 10, 13; van den Berg et al 2008, 330).

\section{The Canadian Case: 'Employment Insurance'}

The Keynesian welfare state model, dominant until the mid-70s in Canada, advocated using economic policy to "keep both inflation and unemployment in check" (Finkel 2006, 286). It maintained that citizens should be assured a "modest level of economic security and social support" and was intended to deal with inequalities generated as a result of the capitalist free market system (Mulvale 2001). This notion of the welfare state, however, has been 'restructured' over the past few decades. Now, what were formerly state responsibilities, such as forms of social assistance, for example unemployment insurance, have been downloaded - first to the provincial level, then to 
the municipal level, and finally onto the family and the individual (Man 2002; de Wolff 2002). This restructuring began partly as the result of the oil crisis that took place in the 1970 s, which led to economic recession and the view that the State could no longer support every one of its citizens (Man 2002). The 'restructuring' of the social welfare state model resulted in the rise of a new political-economic ideology called "neo-liberalism": a perspective that holds that state-run enterprises should be privatized and that capitalist markets should be the central organizational principle of all society. Under neoliberalism, the responsibility of the individual for their own fate is central and government's involvement in private issues is avoided (Burke and Silver 2006).

Canada is a vast country with a variable set of economic conditions and industrial sectors (van den Berg 2008). The unemployment rate in Canada also varies from region to region due to high levels of seasonal employment (van den Berg et al 2008). Canada also has a decentralized federal government structure and it is more difficult to modify labour policy as a result of the power of the provinces; this fact alone significantly distinguishes Canada from Denmark (van den Berg et al 2008, 307). In 1996 to 1997, under the influence of neo-liberal ideology, worker's rights underwent a major change, as the federal government reformed Unemployment Insurance (UI) and renamed it Employment Insurance (EI) (van den Berg et al 2008). This legislation, Bill C-12, initiated a number of changes including hours based eligibility, new requirements for new workers and re-entrants to the labour market, a reduced benefit time period of 45 from 50 weeks, a reduction in the maximum amount of benefits, harsher benefits calculation, and the intensification of benefit repayment once the worker is no longer unemployed (van Den Berg et al 2008).

The motivation behind the change to EI was a desire to reduce individuals' reliance on the state, while continuing to provide some form of "shock absorber" for times of labour market fluctuation (Battle et al. 2010; Bezanson and Murray 2000). While the UI / EI switch improved the annual deficit and federal public debt, critics point out that these savings were made at the expense of unemployed workers (van den Berg et al 2008, 309). The significance of the policy change is apparent in the change of name from "unemployment" insurance to "employment" insurance, signaling a shift in labour policy from supporting the unemployed to creating employment; strict limits on state support were put in place with the hope that this would effectively force individuals into the labour market (van den Berg et al 2008). While it has been argued that the labour force has adjusted to the new EI eligibility rules, because of the changing and increasingly unstable and precarious labour market, many Canadian workers are currently unable to access the benefits of EI at all. While this may have been a goal of the policy reform, it is difficult to ascertain how, exactly, it reduces individual reliance on state support, as many of those forced off EI simply end up turning to social welfare programs instead (van den Berg et al 2008; Porter 2003). Recently, in May 2012, EI requirements were tightened once again, when Canadians were told they would have to look for a job every day they receive 
benefits and should be prepared to take any job on offer within reason. This policy shift suggests that there are no bad jobs, only lazy workers (Coles 2012).

The result of the limited view of employment expressed in Canada's EI policy is that those who have a long term, secure job see this security continue; they can relatively easily access EI should they lose their jobs. Those who must work precarious, low paying or seasonal jobs, however, have no recourse should they lose theirs. With more and more women and lower income people relegated to precarious employment, we must question whether EI policy is actually in touch with the realities of work on the ground. We must ask: does current EI policy work to ameliorate all workers' vulnerability and help to address broader issues of social inequality or does it effectively exacerbate them? If, as it appears, EI does not work either to support Canadian workers or to address broader issues of social inequality, then we must strive to implement a viable alternative. Could an alternative system be modeled on the flexicurity system now in effect in Denmark?

\section{Could Flexicurity Help Canadian Workers? Social Justice for the Globalized Worker}

Political philosopher Nancy Fraser contends that we need to adopt "some normative criteria" $(1997,44)$ in order to propose ways to address the changing needs of the globalized worker. In what follows, I will evaluate and compare the Canadian Employment Insurance program and the Danish flexicurity model against four of Fraser's "seven distinct normative principles": (1) the anti-poverty principle, (2) the antiexploitation principle, (3) the income-equality principle, (4) the leisure-time-equality principle, (5) the equality-of-respect principle, (6) the anti-marginalization principle and (7) the anti-androcentrism principle (Fraser 1997, 45-48). Focusing specifically on the ways flexicurity policy and current Canadian EI policy address the anti-poverty, incomeequality, anti-exploitation, and anti-marginalization principles, I will attempt to tease out the successes and failures of both systems. This will allow me to evaluate and compare each system and assess the appropriateness of flexicurity for the Canadian context.

\section{a) The anti-poverty principle}

This principle is concerned with the impoverishment of vulnerable people, most notably workers (Fraser 1997). A successful policy or program should help to avoid the "mitigated exploitable dependency" (Fraser 1997, 46) of workers on the state or any employer for the means to meet their life needs. Elements to consider when assessing whether a program or policy is "anti-poverty" include living standards, the amount of low wage work, the impacts and effects of public spending, the conditions of unemployed workers, and the standard rate of unemployment. The anti-poverty principle is arguably the most important principle for workers, as socio-economic class positions are generally 
dictated to a significant degree by the specific labour market conditions of a nation or society.

Under flexicurity in Denmark there have been moderate increases to wages throughout the country, which in turn have led to a rise in the standard of living (Jørgensen 2009). Interestingly, while standards of living are on the rise, Danes work fewer hours a week in comparison to Canadians (Westergaard-Nielsen 2008). One of the ways Denmark achieves this is by requiring that temporary contracts become permanent contracts after 2 years of continuous temporary work (Muffels 2008; Auer 2000). In Canada, there is no such requirement. While most Canadians are employed in permanent full time work, 40 percent of women and 30 percent of men are employed in unstable, short-term forms of non-standard work (Townson and Hayes 2007), and, as a result, more and more Canadian workers are forced to hold multiple jobs in order to make ends meet (Townson and Hayes 2007, 20). Given this instability in the workforce, it is difficult to ascertain the true standard of living in Canada in terms of an individual's ability to maintain a living wage. So, while temporary work exists in both Denmark and Canada, the possibility of achieving a stable living wage is far greater in Denmark than in Canada. By guaranteeing steady employment after two years to all workers, poverty is more easily avoided.

Both countries should be concerned about poverty traps in their economies and within their workforce. Some critics argue that the flexicurity system keeps low-wage workers in poverty (Vermeylen 2008) because employers can hire and fire in relation to the performance of the market (Pedersen et al 2007). Denmark, however, has the lowest rate of low-wage work among countries like France, Germany, and the United States (Solow 2008). While Denmark has a lower average disposal income at $\$ 26,562$ (US Dollars) as compared to Canada at $\$ 32,047$ (US Dollars) (OECD Statistics Average Annual Wage), in Canada almost half of the workers, 44 percent or 13,821,870 Canadians, earn less than $\$ 25,000$ a year, meaning that there is a significantly high proportion of low-wage workers there (Statistics Canada CANSIM 111-0008). Clearly, Canada's "stringent labour market regulations on permanent workers" produces a dual labour market in which there is a segment of permanent, better protected workers and a large segment of unprotected precarious workers $(2009,548)$. As the persistence of a class of "working poor is not a policy option" (Andersen and Svarer 2007, 393), Robert Solow contends that flexicurity might be the best way out of low wage work in neo-liberal times (2008).

Denmark has high levels of public spending, which is often associated with a large individual tax burden (Lewchuk 2010; Westergaard-Nielson 2009). Part of this public spending is dedicated to providing Danish unemployed workers with a generous social safety net. But, the entire system is premised on the idea that unemployment can be kept low by improving employers' ability to train employees well (Pedersen et al 2007; Lewchuk 2010; Andersen and Svarer 2007). The question remains as to whether the 
system would be able to maintain the social safety net at its current levels if the unemployment rates were to rise. One notable problem with flexicurity, then, is that it may not be able to adapt to major economic shifts or downturns since it is very dependent on high levels of government spending (Viebrock and Clasen 2009).

Canada spends far less on labour market policies and has a far more passive labour market protection system overall (Lewchuk 2010). The "OECD Public Social Expenditure on Labour Market Policies" document notes that Canada spends 0.29 of GDP on active policies, as opposed to 0.56 on passive policies (Lewchuk 2010; OECDStats Extract). On the other hand, Denmark spends 1.51 of the GDP on active policies, as opposed to 1.86 on passive policies (Lewchuk 2010; OECDStats Extract). This illustrates the fact that Denmark is more willing to draw from the overall tax base to invest in its workers and, by extension, its economy. So, interestingly, while both countries are under the influence of neo-liberal ideology, in Canada public spending has been cut and workers must face economic hardship on their own (Burke and Silver 2006), while in Denmark, high levels of public spending go toward supporting workers, and, by extension the Danish economy overall.

Denmark's high level of social support permits it to offer the lowest level of employment protection in Europe, thus enabling employers to take on more risks (Westergaard-Nielsen 2008; Lewchuk et al. 2011). For example, the system allows for the dismissal of workers on short written notice and does not require third party involvement like other systems in the Anglo-Saxon model (Madsen 2008). This places Denmark low on the OECD rankings of employment protection, in a similar location to Canada (van den berg et al 2008); Canada ranks the $4^{\text {th }}$ lowest on employment protection, while Denmark ranks just below the average (Lewchuk 2010). Worker exploitation, however, is greater in Canada; it ranks the $4^{\text {th }}$ lowest for the provision of unemployment benefits and, is, overall, the $5^{\text {th }}$ lowest active labour market country in the OECD. Denmark, on the other hand, is the $2^{\text {nd }}$ highest for unemployment benefits and ranks the highest for active labour market policies (Lewchuk 2010). ${ }^{3}$ Thus, while some on the right might argue that Danish workers are exploited by high levels of taxation, Danish society puts that tax money back into supporting citizens and improving the situation of those citizens who are unemployed (Westergaard - Nielsen 2008). Is the heavy taxation spent to avoid exploitation of workers in Denmark a better alternative to the system now in place in Canada?

There are similarities between Denmark and Canada in terms of their respective social safety nets, however. For instance, all workers are covered by basic health care in both countries (Westergaard-Nielsen 2008). In addition, services, such as education, are

\footnotetext{
3 There are many factors that can be seen to contribute to 'exploitation' within the labour market. I include, for instance, low labor market activity and levels of social spending. For an historical account of labour market exploitation, see James W. Renehart (2006).
} 
subsidized by the public purse (Westergaard-Nielsen 2008). Both countries also have state-run unemployment insurance systems, although there are differences between them (Jørgensen 2009). In Denmark all employees receive coverage; even those who do not pay into a benefits system receive cash benefits. Canada, however, is quite different (Lin 1998), as all workers must pay into the unemployment insurance system whether or not they are eligible to receive benefits. Given these numbers, it is no surprise that Danes are less afraid to be unemployed, as Jørgensen notes (2009), but Canadians have good reason to be. In Canada at least, it seems clear that the EI system does not work to address or alleviate poverty.

Denmark, on the other hand, can be seen as a model of a dynamic labour market that can simultaneously help to end economic hardships and support workers, moving them away from poverty (Viebrock and Clasen 2009). Many have noted that moving workers from low levels of industrial production to higher levels of employee output, as flexicurity does in Denmark, creates more jobs (Lewchuk 2010). As short-term contracts produce less concern on the part of employers for the training or health of their employees (Lewchuk 2010), state support in Denmark picks up the slack in contract and employment relationships by providing child care and early retirement schemes, among other resources (Larsen 2005; van den Berg et al 2008; Jørgensen 2009). In Canada, stable, secure jobs are no longer considered "cost-effective" by many businesses, but the state has not stepped in to support workers as they struggle to contend with the increasingly precarious labour market (Scott-Marshall 2007; Gindin and Stanford 2006). Workers in Canada currently experience wage stagnation, job deskilling, fewer full time jobs, the deterioration of opportunities for job advancement, lack of health support from employers and increases in expected overtime hours (Scott-Marshall 2007). All of this has important, negative implications for the Canadian worker.

In Denmark, unemployment has been reduced to levels below France and Germany and labour market participation has increased to 77.4 percent (Solow 2008; Lewchuk 2010). According to Wayne Lewchuk, most unemployed people in Denmark make their own way back to the labour market, with only a few opting for flexicurity retraining programs (2010); the most common form of worker reactivation within Denmark occurs via higher education and vocational training (Lewchuk 2010). While the unemployment rate is currently lower in Canada ${ }^{4}$, the statistics do not include those who have given looking for work or who cannot access job retraining and educational programs due to a lack of resources. The social supports in Demark, then, help to reduce poverty levels, and entrenched, generational poverty is less of a concern than in Canada.

b) The income-equality principle

\footnotetext{
${ }^{4}$ The unemployment rate in 2012 was 8.2 percent (World Bank UEM.TOTL.ZS), while in Canada it was 7.2 percent as of June 2012 (StatsCan Labour Force Survey 2012).
} 
Following many others, Nancy Fraser contends that income equality is essential for both gender equality and worker equality (1997). As Greet Vermeylen (2008) and other scholars, such as Wilkinson and Picket (2010) argue, income insecurity and large discrepancies in income between rich and poor hurt all citizens. Would a hybrid system like flexicurity, which does not restrict employment practices but provides economic protections for workers, help to achieve more income equality in Canada (Madsen 2006)?

In Denmark, approximately 25 percent of workers change jobs each year, with new workers changing employers frequently as a result of skills development programs (Vermeylen 2008; Madsen 2008; Madsen 2006; Lewchuk 2010; Muffels 2008). However, due to relatively generous social protections, this high level of turnover does not have much impact on workers' socio-economic position (Vermeylen 2008; Lewchuk 2010). Danes receive 90 percent of four weeks work to a maximum of approximately 400 Euros a week while on unemployment, with no waiting period, for a maximum of four years and must take retraining programs after approximately one year of unemployment (Madsen 2008; Madsen 2006). Even workers who are not insured can apply for cash benefits (social assistance) from their local municipality during times of unemployment (Jørgensen 2009; Madsen 2008). Youth workers under 25 have modified coverage; they are only covered for a maximum of 6 months (Westergaard - Nielsen 2008).

This is a large contrast to Canada where, as we've seen, EI reforms have been successful in cutting benefit payouts along with the overall number of EI recipients (van den Berg et al 2008). EI policy has changed the definition of labour market attachment wherein a claimant must have contributed 180 days within the past 2 years. Eligibility is based on a 35 hour week, rather than the number of weeks worked. The overall increase in the amount of time required to work at least doubled with the shift to EI (2007; Finkel 2006); while the UI program required 20 weeks at 15 hours or 300 hours worked, EI requires 20 weeks at 35 hours a week or 700 hours worked ( (Townson and Hayes 2007; Torjman 2000). In addition, the requirements for new applicants have been standardized across the provinces (Battle 2009; Townson and Hayes 2007). Ken Battle points out that before the transfer to the EI program, the average benefit was 595\$ a week, while in 2009 the coverage was $447 \$$ weekly or $\$ 22,350$ yearly (2009). It is no surprise, then, that the Canadian unemployment benefit payout system is considered one of the most restrictive in the OECD countries, reflecting an entirely different neo-liberal policy approach to that of Denmark (van den Berg et al 2008). Given these facts, it seems clear which system would be most desirable from the point of view of an unemployed worker; even in times of unemployment, Danes are able to maintain up to $90 \%$ of their income and, as a result, national levels of income equality are maintained (Madsen 2008).

Although there is no legislated minimum wage in Denmark, there is also less income inequality and poverty (van den Berg et al 2008; Westergaard-Nielson 2008). Through flexicurity, wages and job quality are maintained by an unregulated labour 
market, with a standard wage agreed upon by social partners; as of 2005 this wage was 15 US dollars an hour (Solow 2008). So, even though low wage work exists in Denmark, the difference from the Canadian situation is that low wage workers are "jobless but not penniless" (Westergaard-Nielsen 2008, 29). It is clear that those with lower income are better off in Denmark than in Canada (van den Berg et al 2008).

c) The anti-exploitation principle

This strategic principle insists on the prevention of "exploitation of vulnerable people" (Fraser 1997, 46) and involves examining which system best protects workers from employer or state exploitation. The social protections embedded in flexicurity are specifically designed to reduce risks to workers (Van den Berg et al 2008; Vermeylen 2008) and are maintained through heavy taxation (Solow 2008; Jørgensen 2009). But, does this taxation truly help the worker?

When assessing a system like flexicurity in Canada, especially its ability to address exploitation, we must assess the potential social costs of heavy taxation and especially the dominant cultural attitude toward taxation. In 2008, Denmark's total tax revenue was 48.2 percent of the GDP while Canada's was 32.3 percent of GDP (OECD DataCode 4672109 Table A). It remains a crucial question whether or not Canadians would accept an increased tax rate in order to implement better protections for workers. After all, Denmark has a well established history of high taxation rates, whereas Canada, arguably influenced by opinion trends in the United States, seems far less tolerant of increasing taxes, no matter how well spent they might be. And, as discussed above, flexicurity depends on very low unemployment levels; it requires almost full employment in order to collect the tax money needed to fund the social safety net (Westergaard - Neilson 2008).

As the standard employment relationship eroded in Denmark throughout the 1990s, it was replaced by long-term temporary contract work, which allowed employers to provide little support for their workers' health beyond the workplace or proper long term training (Lewchuk et al 2011). Flexicurity was implemented to address these issues of worker health and training, and overall, it has been successful at raising job satisfaction rates (Lewchuk 2010); 90 percent of Danes are currently employed on long-term contracts (Lewchuk 2010; Lewchuk et al 2011). However, for both countries, long term temporary work has consequences, especially in terms of the workers' physical and mental well being (Näswall and De Witte 2003), and there are limits as to how much government programs can provide. As Greet Vermeylen notes, workers should "be able to plan their lives" $(2008,208)$, and not fear being dismissed at any time. Without supports from the employer both inside and outside the workplace, temporary workers in both countries are rendered more socially and economically vulnerable.

Since the 1960s, labour markets have been segmented between the primary sector, which includes higher income, skilled and secure employment, the possibility for 
promotion, and is characterized by white male privilege (Peck 1997; Krahn et al 2008; Reich 1973), and the secondary sector, which includes less skilled or desirable jobs, poor wages and working conditions, feminization and insecurity (Peck 1997; Reich 1973; Krahn et al 2008). This segmentation has only intensified with the entrenchment of precarious, short-term, and contract work. Indeed, many labour market segmentation theorists highlight the fact that employers divide workers against each other in order to control the mode of production (Peck 1996; Reich 1973), actively contributing to social and class inequalities instead of ameliorating them (Peck 1997; Reich 1973). In Denmark, most individuals remain susceptible to easy dismissal, and must, therefore, still be considered precariously employed, although they have more state protections than Canadians do. In Canada, those individuals within the secondary labour market, between 30-40 percent of all workers, do not qualify for unemployment benefits at all (Townson and Hayes 2007). Given the more highly segmented nature of the Canadian labour market, then, we can assume that patterns of social inequality are more entrenched in Canada than they are in Denmark.

It is clear that Denmark and Canada took different paths through neo-liberalism in the 1980s and 1990s. While private interests seem to have become the primary focus of most state governments and this has resulted in the cutting of social programs, Denmark has managed to hold on to its commitment to care for its citizens (Burke and Silver 2006). While flexicurity is a product of neo-liberal interests and is far from recreating the era of Keynesian economic security and social supports (Mulvale 2001), it does recognize that a state cannot simply abdicate responsibility towards its citizens. Flexicurity actively avoids worker exploitation by encouraging both capitalist-friendly neo-liberal market flexibility and Keynesian social supports for workers, that enable workers to have some alternative to market participation. As Esping-Anderson would emphasize, this means that labour is partly decommodified under the Danish model of flexicurity with important benefits for workers and their relative power to capital.

Denmark's social welfare not only gives the worker benefits but also social duties, however. For example, workers must take work when it is offered or enrol in another form of worker reactivation, such as training or retraining programs (Jørgensen 2009). Job retraining to fit labour market needs improves employability and wages, and therefore leads to a better quality of life. Lewchuk notes that most Danes believe that worker activation has a positive effect; 70 percent indicate a better quality of daily life, 58 percent note better self esteem, and 50 percent have better labour market qualifications. Only 25 percent have a negative view of job training (2010). In contrast, neoliberal policies in Canada have significantly deregulated social programs and services or cut them off from state funding entirely, and labour laws and organizations have been seriously weakened (Pulkingham and Ternowetsky 2006). So, while in Denmark retraining programs and social supports help to ameliorate inequality by training workers and reducing the wage gap, in Canada a lack of social supports and retraining programs 
clearly disadvantages the unemployed and further entrenches already existing social and class inequalities.

d) The anti-marginalization principle

Fraser argues that the welfare state satisfied all the principles named above and yet still managed to marginalize women (1997). With Fraser, I would suggest that social policy should encourage the full participation of all society's members (Fraser 1997). So, in order for us to deem a system of worker protections successful, it must be shown to ameliorate the conditions of marginalized workers, especially but not only women.

Many contend that flexicurity aims to create social cohesion while addressing poverty and exclusion (Wilthagen 2008). However, in some ways, workers under the flexicurity regime in Denmark are just as unprotected as American and Canadian workers (Westergaard-Nielsen 2008). For instance, Lewchuk notes that the generous supports provided in Denmark have made immigration popular, among other factors, but that the benefits actually available for immigrants are fewer than those available to Danish citizens (2010). In 2001, the Danish government reduced immigrant access to benefits for the first seven years they are in the country (Brodmann and Polavieja 2011). Stefanie Brodmann and Javier G. Polavieja highlight the wide gap between the employment rates of immigrants and those of native-born Danes, and note that immigrants often suffer from shorter periods of employment and longer periods of unemployment (2011). This situation creates a secondary labour market in Denmark similar to the one in Canada, and marginalization remains a significant concern. Arguably, then, the success of flexicurity is tied to Denmark's strict immigration policies, and Canada's relatively open if increasingly restrictive immigration policies would have to be reconsidered were flexicurity to be applied - with the effects of further entrenching inequalities among citizen and non-citizen workers.

Similar to Denmark, immigrants in Canada have difficulty gaining employment due to the undervaluing of their foreign experience (Knowles 2007). Immigrant women, especially, are marginalized in Canada. As Sedef Art-Koç argues (1999), while new settlement programs assert that they are 'genderless', not biased, and based solely on 'deserving' and 'non-deserving' immigrants, these programs often fail to assess the already entrenched sexism within immigrant communities. Since Canada's immigration point system stresses the ability to contribute economically, it automatically favours male immigrants, as many women coming from other parts of the world do not have the education, freedom, or resources to be able to make a contribution to the Canadian economy when they first arrive (Art-Koç 1999). This bias only continues as female immigrants, in particular, attempt to find work; they are often relegated to precarious, short-term jobs and, as a result, tend to be shut out of the employment insurance benefit program. 
Security and flexibility are also lower for women in Denmark (Muffels 2008). Scarce resources for childcare and household work can increase female unemployment and labour inactivity (Muffels 2008) and, conversely, when women do participate in the labour force, their work in the home can be affected (Muffels 2008). In Denmark, jobs have remained very much 'gendered' (Westergaard-Nielsen 2008) even while flexicurity ostensibly addresses the entrenched male breadwinner model (Lewchuk 2010) by emphasizing a universal worker system and dealing with gender differences in life changes. As in Denmark, Ken Battle indicates that the gender gap in the Canadian society overall had risen dramatically from the mid-1980s to mid-1990s, when the gap was the smallest (2009); currently one-third more men than women are eligible to receive EI benefits (Battle 2009). Given these facts, then, it does not seem as though either of these nations' employment policies have effectively addressed the issue of gender equality in the workforce. However, flexicurity does, at least theoretically, adopt a universal breadwinner model, which supports the view that both men and women should participate equally at work and in the home.

The issue of job tenure also must be part of any evaluation of worker marginalization. In Denmark, the tenure rates are slightly lower than the rest of Europe and even lower for women (Lewchuk 2010; Madsen 2008); Danish women can expect to keep a job for an average of 8 years. There are few studies on job tenure in Canada (2010), although Lewchuk points out that Canadian tenure rates for all workers increased by ten percent between 1976 and 2006 (Lewchuk 2010), there does not seem to be clear data on the breakdown between genders. All research shows, however, that limited education reduces the chance of a permanent employment (Muffels 2008). It is no surprise, then, that tenure rates increase with education in Denmark (Madsen 2008). Interestingly, the number of welfare recipients in Denmark only marginally decreased in the 1990s as a result of flexicurity (Lewchuk 2010). On this score, it is difficult to evaluate which worker protection system performs better. Suffice it to say that the longer an employee is in a permanent employment relationship, the more the employer would want to invest in them, and hence social and class marginalization would be reduced for the worker.

There also appears to be marginalization of older and disabled workers in Denmark under flexicurity (Lewchuk 2010). Due to the high degree of turnover that occurs in the Danish work world, the system tends to create more advantages and opportunities for young workers and those trying to return to work (Lewchuk 20104 ). Workers over 30 must accept a retraining program after a year of being unemployed, and, as a worker's age increases it becomes more and more difficult for them to qualify for retraining (Lewchuk 2010). Few employment regulations and the fact that workers can be easily dismissed also militate against older or disabled workers (Lewchuk 2010, 51; Westergaard-Nielsen 2008). As Julie Ann McMullin and Kim M. Shuey note "Canadian data shows that labour-force participation rates and employment status are influenced by the intersection of age and disability: older, disabled working-age adults have lower 
labour-force participation rates and higher unemployment rates than either younger adults with a disability or older adults without a disability" $(2006,832)$. So, there is a structural barrier to access to employment for older workers and disabled workers in Canada as well (McMullin and Shuey 2006). Again, in this area, neither system has it right.

Table 1. Comparing Denmark and Canada's Labour Market Policies Against Nancy Fraser's Four Principles of Justice for the Globalized Worker

\begin{tabular}{|c|c|c|}
\hline Principle & Denmark & Canada \\
\hline anti-poverty & $\begin{array}{ll}\text { - } & \text { moderate wage increase } \\
\text { - } & \text { improved standards of } \\
& \text { living } \\
\text { - } & \text { work fewer hours } \\
\text { - } & \text { after } 2 \text { year temporary work } \\
\text { contract becomes } \\
\text { permanent } \\
\text { - } \quad \text { low- wage work } \\
-\quad \text { high tax burden } \\
-\quad \text { low level of employment } \\
\text { protection } \\
\text { - } \text { high spending on active and } \\
\text { passive labour market } \\
\text { policies }\end{array}$ & 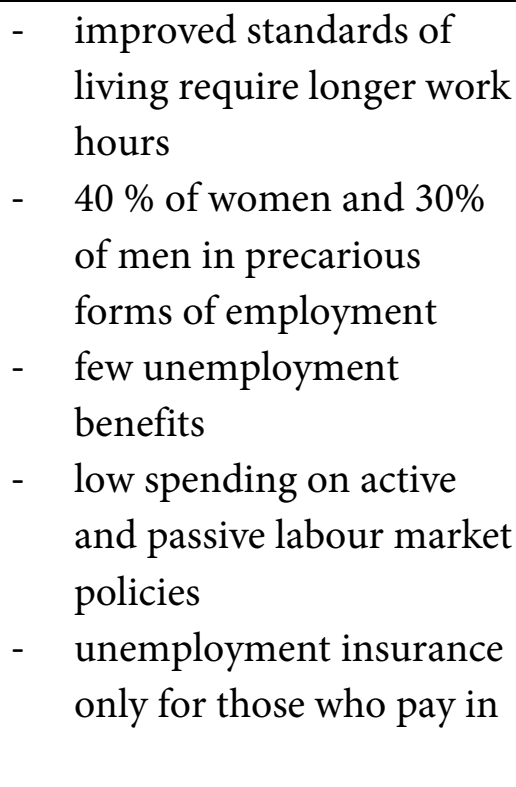 \\
\hline income equality & $\begin{array}{ll}- & \text { high job turn over (25\% per } \\
\text { year) } \\
\text { - } & \text { significant unemployment } \\
& \text { benefits for all }\end{array}$ & $\begin{array}{l}\text { - low unemployment } \\
\text { benefits for some }\end{array}$ \\
\hline anti-exploitation & $\begin{array}{ll}\text { - } & \text { high taxation rates } \\
\text { - } & \text { frequent mobility hinders } \\
& \text { lifelong planning } \\
\text { - } & \text { worker reactivation }\end{array}$ & $\begin{array}{ll}\text { - } & \text { temporary contract } \\
\text { workers do not qualify for } \\
\text { unemployment benefits }\end{array}$ \\
\hline $\begin{array}{l}\text { anti- } \\
\text { marginalization }\end{array}$ & $\begin{array}{ll}\text { - } & \text { immigrants do not receive } \\
\text { same employment } \\
\text { protections as citizens } \\
\text { - } \quad \text { tenure rates in Demark } \\
\text { increase with education } \\
\text { - } \quad \text { age discrimination for } \\
\text { retraining and reactivation }\end{array}$ & 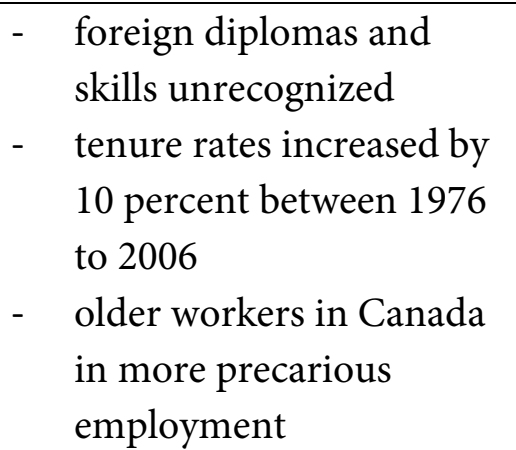 \\
\hline
\end{tabular}




\section{Conclusions}

The principles outlined by Nancy Fraser help illuminate some of the respective problems and strengths of the Danish and Canadian unemployment systems. Neither one seems sufficient to protect the current globalized worker. One must question whether choosing between high taxes or job security is really a fair choice (Madsen 2006), although arguably from a worker perspective clearly job security is most critical. Moreover, in practice, flexicurity seems to depend on making distinctions between citizen and non-citizen workers, with the latter exposed to much more precarious and difficult working conditions. At the same time, however, we must recognize that there are some elements of the flexicurity system that could be good for Canada.

The Danish model of flexicurity has been referred to as "an example of how to achieve high levels of employment and sound public finances in a socially balanced way" (Viebrock and Clasen 2009, 321). It is important to note that it is based on "ambitious equalitarian objectives" (Andersen and Svarer 2007, 393), in the sense of ensuring the unemployment is not automatically synonymous with poverty. It is also important to note that it cannot be simply "cop[ied] and past[ed]" into another national context (Andersen and Svarer 2007, 390); specific economic, political, and cultural factors play into the success of any labour market policy (Jørgensen 2009; Wilthagen 2008).

Improvements and adaptations would certainly have to be made if a version of flexicurity were to be applied to countries with different traditions and population levels. In order to bring flexicurity in line with social democratic goals, improvements would be most definitely need to be made, including equality of treatment for citizens and noncitizens, rights within transitions between jobs, improved insurance periods and improved transferability of rights (Vermeylen 2008).

Moreover, as Joël Decaillon, Deputy General Secretary of European Trade Union Confederation (ETUC) states, "flexicurity is a concept that is being used in every possible way." Too often, it simply means flexibility for the employer, without important protections for workers. And, as Decaillon insists, "Flexibility does not create jobs". He concludes, "to put it at the core of the remedies to the crisis is a mistake. For the most vulnerable employees, young people for example, this approach boils down to making their jobs precarious" (Grillo, 2011). Clearly, only specific elements of flexicurity should be adopted if the aim is to improve current Canadian labour market policies, so that they are in the interests of workers. These elements focus primarily on increasing support for workers and on providing wide scale social improvements. For instance, in order to reduce poverty, Canada should work to reduce the number of low wage jobs and adopt the requirement to make temporary jobs into permanent jobs after two years at the same temporary position (Muffels 2008; Auer 2000). While taxes are higher in Denmark, the proceeds of these taxes are spent on active labour market policies that support worker 
retraining and skill development (Lewchuk 2010). More investment in vocational education and worker training should be adopted in Canada. The generous state support for Danes when unemployed should also be adopted by increasing the rates of unemployment insurance payouts (Larsen 2005; van den Berg et al 2008; Jørgensen 2009). This last is especially important for decreasing worker support on the market nexus, so increasing the workers relative bargaining power vis-à-vis capital -- since this enables workers to refuse badly-paying or dangerous employment.

Flexicurity's focus on a universal breadwinner model should also be adopted in Canada; men and women need to be treated equally when it comes to state support for work in and outside of the home. These social support elements of flexicurity could help to balance out of some of the more pernicious effects of neo-liberal economic and social policies in Canada.

However, we need to be cautious about other elements of flexicurity. For instance, we should carefully examine the implications of continual job turnover that occurs in Denmark (Vermeylen 2008). Workers need to be able to plan their future, which is difficult to do when they change jobs frequently. These kinds of changes would clearly have an impact on broader social cohesion. Also, while flexicurity claims to be universal, we have seen how immigrants receive fewer benefits and younger workers receive more benefits than older and disabled workers (Lewchuk 2010). These inequities would surely have to be addressed before any adaptation of the policy to the Canadian context.

A solution may be to combine some elements of flexicurity with other labour market policies. As Lewchuk notes, there are other ways that security can be increased in Canada, including the project of ensuring a guaranteed annual income (Lewchuk et al 2011). The Canadian labour market likewise must adopt a "global package of social rights" as a way to avoid income insecurity and the poverty trap (see for instance Vermeylen 2008, 206). Arguably, Canada does not need to adopt flexicurity wholesale, as in the Danish model. Rather, it needs better protection for workers, such as increased severance payments for temporary contracts, universal and accessible unemployment insurance for all workers, including precarious short-term contract workers, and a universal income program to ensure a basic minimum wage.

With the increase in the numbers of non-standard and precarious jobs in the Canadian labour market, it is clear we need to entirely re-think the current EI policy and come up with some different social strategies to avoid unemployment. Lewchuk explores work-sharing policies, illustrating how many companies have avoided layoffs through their use (2010). Should the government subsidise paid time-off, such as "family leave, paid sick days, paid vacations, shorter work weeks or some combination" (Lewchuk 2010, 67 ) in order to encourage these workers to remain employed? These are just a few of the recommendations analysts have made in order to address the problems with current EI 
policy that are better alternatives than the wholesale importation of flexicurity into Canada.

Ultimately, flexicurity is a programme that emphasizes individual worker adaptation, not systemic problems. In flexicurity, the assumption is that with properly skilled workers, unemployment will be zero percent; clearly, this is unrealistic and likewise assumes that labour market policies are the sole determinant of employment rates. As a policy position, flexicurity expresses an ideological position that is damaging to workers by assuming that neoliberal labour market deregulation is here to stay and cannot be changed. If we were to consider importing a version of it to Canada, we should see it as a short-term solution, rather than a long-term goal. If we were to get its implementation right, however, it could lead to the creation of a more equitable labour market for all and strengthen workers bargaining power vis-à-vis capital by creating some alternative to market participation.

Finally and more broadly, Guy Standing argues that governments and society as a whole should focus on implementing occupational security for everyone (2002). He defines occupational security as an individual's ability to combine her/his various capabilities in creative ways and to define his/her work for themselves in terms of their own views about intrinsic value (Standing 2002). Standing argues that focusing only on labour market or economic security increases forms of social inequality, puts many workers into harm's way, and results in a generalized social condition of worker alienation and exploitation (2002). This outlook, combined with the positive social supports of flexicurity, points to other concerns around workers and labour markets.

It is clear that the current labour market policies in Canada need to be reformed and new policies put in place, and workers must be actively involved in analyzing and transforming injustice and helping to shape governmental policies. I have argued here that flexicurity, properly implemented, might offer some important, immediate gains for Canadian workers over the current EI labour market model. From a socialist perspective, of course, nothing less than a total transformation in the definitions and meanings of work, unemployment and social responsibility must be undertaken to counteract the effects of the neo-liberal ideology now dominant in Canadian social policy design. Only then can we begin to move not just beyond neo-liberalism but what socialists see as an unjust world capitalist system.

\section{Work Cited}

Ales, Adoardo. 2008. "Modernizing the European Social Model by a 'Leonine Partnership': The Socially 'Irresponsible' Enterprise in the Age of Flexicurity." In Social Responsibility in Labour Relations: European and Comparative Perspectives. 
Edited by Frans Pennings, Yvonne Konijn and Albertine Veldman 251-276. Alphen aan den Rijn: Kluwer Law International.

Andersen, Torben M. and Micheal Svarer. 2007. "Flexicurity-Labour Market Performance in Denmark." CESifo Economic Studies 53 no. 3: 389-429.

Arat-Koç, Sedef. 1999. "Neo-Liberalism, State Restructuring and Immigration: Changes in Canadian Policies in the 1990s." Journal of Canadian Studies, 34 no. 2: 31-56.

Auer, Peter. 2000. Employment Revival in Europe: Labour Market Success in Austria, Denmark, Ireland and the Netherlands. Geneva: International Labour Organization.

Battle, Ken. 2009. “Gender Aspects of Employment Insurance.” Caledon Institute of Social Policy.

Battle, Ken, Sherri Torjman and Michael Mendelson. 2010. “The Deja Vu All Over Again Budget." Caledon Institute of Social Policy.

Bezanson, Kate and Susan McMurray. 2000. "Booming for Whom? People in Ontario Talk About Income, Jobs and Social Programs." Caledon Institute of Social Policy.

Brodmann, Stefanie and Javier G. Polavieja. 2011. "Immigrants in Denmark: Access to Employment, Class Attainment and Earnings in a High-Skilled Economy" International Migration 49 no.1: 58-90.

Burke, Gerhard. 2001. "Working Time: From Redistribution to Modernization." In Changing Labour Markets in Europe. Edited by Peter Auer 55-115. Geneva: International Labour Organization.

Coles, David. 2012. "EI changes punish most vulnerable, bad economic policy: union." Canadian Newswire. Accessed May 28, 2012. http://www.newswire.ca/en/story/980827/ei-changes-punish-most-vulnerablebad-economic-policy-union

Cuypers, Daniel and Evert Verhulp. 2008. "Dismissal Law Proposals and the Flexicurity Strategy." In Social Responsibility in Labour Relations: European and Comparative Perspectives. Edited by Frans Pennings, Yvonne Konijn and Albertine Veldman 331-350. Alphen an den Rijn: Kluwer Law International. 
de Wolff, Alice. 2002. “The Face of Globalization: Women Working." Canadian Women Studies/Les Cahiers de la Femme. 20 no. 3: 54-59.

Gindin, Sam and Jim Stanford. 2006. "Canadian Labour and the Political Economy of Transformation." In Working in a Global Era: Canadian Perspectives. Edited by Vivian Shalla 379-394. Toronto: Canadian Scholars Press.

Grillo, Patricia. 2011. "Flexicurity of How Theory is Not Applied in Practice." ETUC Press Release.

Fraser, Nancy. 1997. “After the Family Wage: A Postindustrial Thought Experiment.” In Justice Interruptus, Edited by Nancy Fraser 41-68. New York: Routledge.

Fredman, Sandra. 2004. "Women at Work: The Broken Promise of Flexicurity." Industrial Law Journal 33: 299-319.

Finkel, Alvin. 2006. "The Welfare State Since 1980" In Social Policy and Practice in Canada: a History. Edited by Alvin Finkel 283-323. Waterloo, On: Wilfred University Press.

Ibsen, Christian Lyhne and Mikkel Mailand. 2010. "Striking a Balance? Flexibilicy and Security in Collective Bargaining." Economic and Industrial Democracy. 32 no. 2: 161-180.

Jacobsson, Kerstin and Niklas Noaksson 2010. "From Deregulation to Flexicurity? The Makeover of the OECD Jobs Strategy." In Mechanisms of OECD Governance: International Incentives for National Policy-Making? Edited by Kerstin Martens and Anja P. Jakobi 119-138. Oxford: Oxford University Press.

Jørgensen, Henning. 2009. Flexible Labour Markets, Workers' Protection and 'the Security of the Wings': A Danish Flexicurity Solution to the Unemployment and Social Problems in Globalized Economies. Santiago de Chile: United Nations.

Knowles, Valerie. 2007. Stranger at Our Gate: Canadian Immigration and Immigration Policy 1540-2006. Toronto: Dundurn Press.

Krahn, Harvey J., Graham S. Lowe and Karen D. Hughes. 2008. Work, Industry and Canadian Society. Fifth Edition. Toronto: Nelson Education Ltd. 
Larsen, Flemming. 2005. "Active Labour Market Policy in Denmark as an example of Transitional labour Market and Flexicurity Arrangements: What can be Learnt?" TLM.NET Working Paper 11: 1-28.

Lewchuk, Wayne. 2010. “It is not your father's (or your mother's) labour market: Evidence Synthesis of the Health Impact of Precarious Employment and Unemployment." Prepared for Public Health Agency of Canada.

Lewchuk, Wayne, Marlea Clarke and Alice de Wolff. 2011. Working Without Commitments. Montreal: McGill-Queen's University Press.

Lightman, Ernie. 2003. Social Policy in Canada. Toronto: Oxford University Press.

Lin, Xhengxi. 1998. "Employment Insurance in Canada: Recent Trends and Policy Changes." Canadian Tax Journal. 46 no. 1: 58-76.

Madsen, Per Kongshøj. 2006. "Labour Market Flexibility and Social Protection in European Welfare States - Contrasts and Similarities.” ABL 32 no. 2: 139-162.

Madsen, Per Kongshøj. 2008. “The Danish Road to 'Flexicurity’: Where are we Compared to Others? And How Did We Get There?" In Flexibility and Employment Security in Europe: Labour Markets in Transition. Edited by Rudd J. A. Muffels 341-362. Cheltenham: Edward Elgar Publishing Limited.

Man, Guida.2002. "Globalization and the Erosion of the Welfare State." Canadian Woman Studies/Les Cahiers de la Femme 21/22, no. 4/1: 26-32.

McMullin, Julie Ann, and Kim M. Shuey. 2006. "Aging, Disability and Workplace Accommodations." Aging and Society 26: 831-847.

Muffels, Ruud. 2008. "Pathways to Flexicurity in Europe: Do they Affect Male and Female Labour Market Transition Pattern?" In Innovating European Labour Markets: Dynamics and Perspectives. Edited by Peter Ester, Ruud Muffels, Joop Schippers and Ton Wilthagen 95-129. Cheltenham: Edward Elgar Publishing Limited.

Mulvale, J. 2001. Reimagining Social Welfare: Beyond the Keynesian Welfare State. Aurora, Ont.: Garamond Press. 
Näwswall, Katharina and Hans De Witte. 2003. "Who Feels Insecure in Europe? Predicting Job Insecurity From Background Variables." Economic Industrial Democracy 24 no. 3: 189-215.

OECD. StatExtracts. 2012. Average Annual Wage. http://stats.oecd.org/Index.aspx\# Accessed March 27, 2012.

OECD. StatExtracts.2012. Gross Domestic Product. http://stats.oecd.org/Index.aspx\# Accessed March 27, 2012.

OECD. StatExtracts. 2011. OECD Employment Protection Index. http://stats.oecd.org/Index.aspx?DatasetCode=LMPEXP Accessed July 20, 2011.

OECD. StatExtracts. 2011. Labour Force Statistics (MEI). http://stats.oecd.org/index.aspx. Accessed March 27, 2011.

OECD. StatExtracts. 2011. Public Social Expenditure on Labour Market Policies 2007 http://stats.oecd.org/Index.aspx?DatasetCode=LMPEXP Accessed July 20, 2011.

OCED DataCode. 2011. Total tax revenue as percentage of GDP. www.oecd.org/dataoecd/48/27/41498733.pdf Accessed July 20, 2011.

Origo, Federica and Laura Pagani.2009. "Flexicurity and Job Satisfaction in Europe: The Importance of Perceived and Actual Job Stability for Well-Being at Work." Labour Economics 16: 547-555.

Peck, Jamie. 1996. Work Place. London: The Gilford Press.

Pedersen, Henrik Stener and Rune Holm Christiansen and Maj Pagh Petersen. 2007. "Denmark: Towards the Individualization of Working Conditions?" The Evolving World of Work in the Enlarged EU: Progress and Vulnerability. Edited by Francois Eyraud and Daniel Vaughan-Whitehead 183-230. Geneva: International Labour Office.

Pillinger, Jane. 2005. "Challenging Times, Innovative Ways of Organizing Working Times: The Role of Trade Unions." CES/ETUC Report.

Pulkingham, Jane and Gordon Ternowetsky. 2006. "Neo-liberalism and Retrenchment: Employment, Universality, Safety Net Provisions and a Collapsing Canadian 
Welfare State." In Working in a Global Era: Canadian Perspectives. Edited by Vivian Shalla 278-292. Toronto: Canadian Scholars Press.

Reich, Michael, David M. Gordon and Richard C. Edwards. 1973. "Dual Labour Markets: A Theory of Labor Market Segmentation." The American Economic Review 63 no. 2: 359-365.

Scott-Marshall, Heather. 2007. "Work-Related Insecurity in the New Economy: Evaluating the Consequences for Health.” In Politics and Neoliberalism: Structure, Process and Outcome. Edited by Harland Prechel, 21- 60. Oxford: Elsevier Ltd.

Solow, Robert. 2008. "Introduction: The Danish Story." In Low-Wage Work in Denmark. Edited by Niels Westergaard-Neilsen 2-15. New York: Russell Sage Foundation.

Standing, Guy. 2002. Beyond the New Paternalism: Basic Security as Equality London: Verso.

Statistics Canada. 2011. Employment Income Statistics. Catalogue 97-563XCB2006062. http://www12.statcan.gc.ca/census-recensement/2006/dp-pd/tbt/. Accessed July 2, 2011.

Statistics Canada. 2011. Individuals by Total Income Level by Province and Territory. Catalogue CANSIM 111-0008. http://www40.statcan.ca/101/cst01/famil105aeng.htm. Accessed July 15, 2011.

Statistics Canada. 2011. Estimates of population, Canada, provinces and territories. Table 051-

0005http://www5.statcan.gc.ca/cansim/a26?lang=eng\&retrLang=eng\&id=0510005 \&paSer $=\&$ pattern $=\&$ stByVal=2\&p1 $=-1 \& \mathrm{p} 2=31 \&$ tabMode $=$ dataTable \&csid $=$. Accessed March 26, 2012.

Torjman, Sherri. 2000. "Survival-of-the-Fittest Employment Policy. " Caledon Institute of Social Policy.

Townson, Monica and Kevin Hayes. 2007. Women and the Employment Insurance Program. Toronto: Canadian Centre for Policy Alternatives.

van den Berg, Axel, Claus-H. Van estorff, Daniel Parents and Anthony C. Masi. 2008. "From Unemployment to Employment Insurance: Towards Transitional Labour 
Markets in Canada?" In Flexibility and Employment Security in Europe: Labour Markets in Transition. Edited by Rudd. J. A. Muffels 307-340. Cheltenham: Edward Elgar Publishing Limited.

Viebrock, Elke and Jochen Clasen. 2009. "Flexicurity and Welfare Reform: A Review." Socio-Economic Review 7: 305-331.

Vermeylen, Greet. 2008. "Mapping Flexicurity in the EU." In Innovating European Labour Markets: Dynamics and Perspectives. Edited by Peter Ester, Ruud Muffels, Joop Schippers and Ton Wilthagen 191-214. Cheltenham: Edward Elgar Publishing Limited.

Vrankulj, Sam. 2009. CAW Worker Adjustment Tracking Project: Preliminary Findings. Canadian Auto Workers. http://www.caw.ca/en/8996.htm

Westergaard-Nielsen, Niels. 2008. "Low-Wage Work in Denmark." In Low-Wage Work in Denmark. Edited by Niels Westergaard-Neilsen 16-31. New York: Russell Sage Foundation.

Westergaard-Nielsen, Niels. 2008. "Statistical Analysis and History of Low-Wage Work in Denmark." In Low-Wage Work in Denmark. Edited by Niels Westergaard-Neilsen 32-103. New York: Russell Sage Foundation.

Wilkinson, Richard and Kate Pickett. 2010. The Spirit Level: Why Greater Equality Makes Society Stronger. New York: Bloomsbury Press.

Wilthagen, Ton. 2008. "Mapping Out Flexicurity Pathways in the European Union.” In Social Responsibility in Labour Relations: European and Comparative Perspectives. Edited by Frans Pennings, Yvonne Konijn and Albertine Veldman 251-276. Alphen aan den Rijn: Kluwer Law International. 